\title{
DESKRIPSI DAN EKSPLANASI DALAM ETNOGRAFI
}

\author{
Syahrizal
}

\begin{abstract}
The work of an anthropologist or ethnographer can not be separated from the process of description and explanation. This task can be regarded as the final stage of the task of an anthropologist in the research process. The research report is directly related to the description and explanation. Descriptions are the defining descriptive research findings, in conformity with the purpose of research in terms of how. While the explanation is an explanation of the phenomenon in the sense why. Descriptions and explanations can be separate, but both are inextricably linked, a researcher can give only a descriptive overview of the research results but can not without any explanatory description. A only descriptive study of fact can not be said scientific, because research must be able to explain why of the phenomenon. This article discusses how the description of the form of social life is running, and then explain why that phenomenon occurs. Making the transition from what to why it is a dilemma, but for ethnographers available resources to make it easier to detect and appreciate supported by the description. Explanation can be identified as a causal explanation and theoretical explanation. Phenomena become clear causal explanation based on the relationship associations of the facts found in the field. While the theoretical explanation is based upon the theory of explanation also means perspective. As Geertz their explanations by theoretical espoused ie interpretive explanation.
\end{abstract}

Keywords: description and explanation, anthropologist, phenomenon

\section{A. Pengantar}

$\mathrm{P}$ enelitian etnografi memiliki beberapa tahap yang kalau diurutkan dari awal adalah tahap mendesain penelitian, tahap turun ke lapangan, dan tahap membuat laporan penelitian. Membuat laporan penelitian merupakan pekerjaan menampilkan data penelitian secara sistematis sesuai dengan tujuan dan rancangan penelitian yang dapat dipahami pembaca. Laporan penelitian tidak hanya menampilkan data lapangan atau deskripsi tetapi juga mengetengahkan penjelasan dari data tersebut.

David M. Fetterman (1989) menjelaskan penelitian etnografi dimulai dengan seleksi pemilihan topik, kemudian menentukan masalah penelitian, masalah penelitian yang dipilih oleh seorang peneliti memandu keseluruhan penelitian. Selanjutnya membuat desain penelitian mencakup dana, alat-alat untuk melakukan penelitian, dan bahkan presentasi dari penemuan penelitian. Bagaimana peneliti menginterpretasikan dan mendefinisikan masalah biasanya merefleksikan salah satu apakah penelitian dasar atau penelitian terapan. Masalah juga menentukan pendekatan penelitian yang paling tepat etnografi, survey, atau eksperimental (Fetterman 1989:13).

Penelitian lapangan atau field work adalah karakteristik yang paling mendasar dari penelitian etnografi. Pendekatan ini membentuk rancangan dari semua pekerjaan etnografi. Etnografi klasik memerlukan enam bulan sampai dua tahun atau lebih di lapangan. Field work adalah penjelajahan, peneliti mulai dengan sebuah survey untuk mempelajari data mendasar tentang bahasa, hubungan kekerabatan, data sejarah, dan struktur dan fungsi dasar dari kebudayaan. Setelah tahap ini peneliti melakukan kajian berkaitan dengan dengan tema-tema dan masalah-masalah berkaitan

\footnotetext{
${ }^{1}$ Penulis adalah dosen tetap jurusan Antropologi FISIP Universitas Andalas, Padang
} 
dengan tujuan penelitian (Fetterman 1989:15)

Field work berakhir ketika peneliti meninggalkan lokasi penelitian, tetapi etnografi terus berlangsung. Beberapa peneliti menghabiskan banyak waktu secara formal untuk menganalisa data dan tulisan etnografi selama mereka melakukan field work. Analisis formal dan penulisan laporan ketika peneliti menjaga organisasi data dan seksi penulisan selama fieldwork. Proses ini lebih sederhana dalam penelitian terapan dibandingkan etnografi tradisional karena klien penelitian terapan mengharapkan laporan singkat dan laporan sementara detail hasil penelitian.

Pada tahap analisis final, peneliti harus mengumpulkan semua catatancatatan, laporan singkat, laporan sementara, paper-paper, rekaman, dan lain-lain untuk menarik semua gambaran bagaimana sistem bekerja dari jumlah data yang sangat besar dan kesimpulan awal. Tahap ini adalah langkah yang paling kreatif dari penelitian etnografi. Peneliti mensintesiskan ide-ide dan sering membuat lompatan logika menuju pada penggunaan pengertian yang mendalam. Pengertian yang tidak diharapkan sering menjadi masalah dan menjadi kombinasi pemikiran yang tidak biasa. Peneliti harus melihat apakah data akan mendukung gagasan-gagasan baru atau membuatnya tidak valid.

Permasalahan dalam paper ini berkaitan dengan tahap akhir dari pekerjaan seorang peneliti yaitu menulis laporan penelitian etnografi. Judul dari paper ini adalah "Deskripsi dan Eksplanasi dalam Penelitian Etnografi" . Inspirasi dari topik ini saya dapat dari dua buah artikel yang bersambung dari Jack Katz (2001) yang berjudul "From How To Why:On Luminous Description and Causal Inference in Ethnography". Artikel ini membahas tentang cara menulis deskripsi yaitu berupa bagaimana (how) kehidupan sosial itu berjalan, dan kemudian menjelaskan mengapa (why) fenomena itu terjadi.

Penelitian etnografi lebih kepada penelitian kualitatif yang mengutamakan observasi, wawancara mendalam, dan observasi partisipasi. Berbeda dengan penelitian kuantitatif yang mengutamakan survey, menggunakan survey dan lebih positivistik. Keduanya memiliki cara yang berbeda dalam deskripsi dan eksplanasi.

Etnografi menekankan pada pendeskripsian bagaimana kehidupan berlangsung atau apa yang dilakukan orang atau bagaimana mereka melakukan, ini yang membedakannya dengan positivistik. Sebagai sebuah masalah praktis penekanan etnografi dalam pengumpulan data sering menghasilkan sebuah deskripsi-deskripsi yang kaya yang kadang membuat lelah peneliti untuk mengolahnya.

\section{$\mathrm{D}$}

B. Pengertian Eksplanasi eskripsi dan eksplanasi adalah konsep yang saling terkait dalam tugas seorang antropolog. Deskripsi berkaitan dengan menggambarkan fenomena yang ditemukan seorang antropolog di lapangan. Memang bisa saja sebuah karya etnografi menampilkan deskripsi saja yang tujuannya untuk pengenalan suatu kebudayaan. Misalnya buku-buku yang diterbitkan oleh Departemen Pendidikan dan Kebudayaan pada masa Orde Baru yang menjelaskan adat istiadat suku bangsa di Indonesia, kemudian buku yang ditulis oleh Koentjaraningrat dkk. Yang berjudul Manusia dan Kebudayaan Indonesia adalah contoh karya etnografi yang bersifat deskriptif. Deskripsi dapat sangat berguna bagi masyarakat umum untuk mengenal suatu kebudayaan atau masyarakat lain, sedangkan eksplanasi merupakan telaah yang berguna untuk memahami fenomena yang terdapat dalam masyarakat terutama berguna sekali bagi masyarakat akademis.

Pada prinsipnya eksplanasi dikelompokkan menjadi dua yang pertama eksplanasi kausal atau oleh Ember dan Ember disebut sebagai eksplanasi asosiasiasosiasi dan eksplanasi teori-teori yaitu eksplanasi yang berhubungan dengan perspektif teoritis yang digunakan oleh seorang antropolog. Misalnya eksplanasi yang ditawarkan oleh antrpologi simbolik jelas eksplanasi interpretif. Bagi Geertz (dalam Saifuddin 2006: 310) analisis kebudayaan bukanlah ilmu eksperimental dalam mencari hukum, melainkan interpretatif dalam mencari makna. Mengetahui dan memahami realitas emik diperlukan dalam pendekatan interpretif. Menurut Geertz memahami bentuk dan isi kehidupan internal masyarakat yang kita 
teliti mirip seperti mengetahui dan memahami peribahasa, menangkap ilusi atau mendengarkan lelucon. Dalam hal ini antropologi simbolik mirip dengan strukturalisme, yang juga menawarkan eksplanasi interpretif, namun jelas berbeda dengan materialisme kebudayaan, yang jelas menawarkan eksplanasi kausal.

\section{a. Jack Katz: Deskripsi yang Bagu dan Eksplanasi Kausal}

$\mathrm{D}$ alam abstrak artikelnya Jack Katz (2001) menyebutkan etnografer sering memulai field work dengan fokus pada tugas-tugas deskriptif untuk menjawab pertanyaan tentang bagaimana (how) kehidupan sosial dihasilkan, dan kemudian mereka akan menjelaskan secara formal pola-pola mengapa (why) yang tampak dari data. Membuat transisi dari bagaimana ke mengapa merupakan adalah sebuah dilema, tetapi bagi etnografer tersedia sumber-sumber untuk memudahkan mendeteksi dan mengapresiasi didukung oleh deskripsi. Pengakuan terhadap data yang bagus sering secara implisit terlihat dalam kesimpulan yang berdasarkan kesimpulan kausal.

Kandungan-kandungan apresiasi kebudayaan mengabaikan kearifan praktis untuk memandu penelitian dan penulisan etnografi., khususnya untuk mempertemukan tantangan dari perpindahan dari 'bagaimana' ke 'mengapa', atau perubahan dari fokus pada mengumpulkan deskripsi kehidupan sosial kepada analisis pengorganisasian data ke dalam garis penjelasan. Deskripsi secara ontologi terpisah dari deskripsi tentang bagaimana orang bertindak menggabungkannya ke dalam penjelasan tentang perilaku mereka. Perbedaan tidak berakar pada filosofi tetapi pada praktek etnografi. Dalam satu bentuk umum tantangan muncul ketika menghadapi banyak data deskriptif dan kemudian menfokuskan pada debat-debat yang bergantung pada masalah-masalah penjelasan. Catatan lapangan dan deskripsi wawancara bagaimana orang bertindak harus dipisah-pisahkan dengan yang relevan untuk perdebatan atas mengapa orang bertindak. Sebagai masalah ptraktis, lintasan untuk tingkat kemurnian di mana deskripsi dan penjelasan muncul sering tidak jelas untuk seorang etnografer sampai sebuah tahap penting yang telah didedikasi secara sadar untuk deskripsi.

Tidak mudah untuk menghindari dilema ini, sebagai contoh dalam mengumpulkan data pada tempat pertama secara harfiah sebagai jawaban pertanyaan 'mengapa'. Mendorong peringatan untuk kewaspadaan peneliti untuk kemungkinan menanya orang 'mengapa' mereka melakukan sesuatu akan menggeser fokus dari apa yang dilakukan peneliti setelah itu, yang mana ini adalah informasi tentang apa yang dilakukan subjek dan pengalaman dalam waktu, tempat, dan aktifitas diluar seting wawancara. Menanyakan 'mengapa' memberikan responden alasan untuk mengantisipasi versi-versi diri yang mereka ekspresikan akan direview oleh peneliti dan orang lain. Responden akan menunjukkan hal-hal yang menyenangkan, penjelasan-penjelasan konvensional, yang barangkali melenakan pewawancara. Kecuali ingin manandai lebih dekat ke retorika konvensional atau studi artefak dari situasi-sistuasi penelitian, data yang dihasilkan dari penelitian 'mengapa' mungkin akan mengecewakan.

'Bagaimana ?' secara umum adalah cara yang lebih baik untuk mendapatkan respon bermanfaat untuk penjelasan karena itu mengundang kesejarahan secara personal, secara sementara respon dibentuk, sementara "mengapa?" memberi kuasa respon dibentuk dalam tidak sementara dan kategori yang tidak persnah dari alasan moral. Menanyakan seseorang mengapa mereka menikah, memilih tempat tinggal, atau mengambil pekerjaan, sering mendapatkan pengesahan singkat yang pokok dari ciri-ciri sekarang dari perkawinan, rumah, atau situasi pekerjaan; ciri-ciri yang mungkin telah ada sejak hubungan dibangun, sebagai realitas sekarang. Merubah pertanyaan ke bagaimana seseorang memperoleh pekerjaan , menemukan tempat tinggal, atau memperoleh bersama dengan pasangan secara umum kembali pada diskusi pada cerita panjang yang menelusuri bagaimana jaringan relasi sosial dan proses detail dari interaksi sosial yang berkaitan dengan status responden sekarang. Tidak umum untuk peneliti menerobos atau memecahkan sebuah penjelasan secara 
khusus dengan merubah pertanyaan yang memandu kepada pengumpulan data dari 'mengapa?' ke 'bagaimana?'.

Jika kita percaya jawaban-jawaban untuk pertanyaan 'mengapa?' , apakah kita tidak akan berada dalam keadaan lebih buruk ?. Jika subjek penelitian dapat dipercaya mengapa mereka melakukan halhal apa yang ingin kita pahami, siapa yang akan membutuhkan kita?. Pertanyaan seperti itu yang sering dilemparkan pada subjek, mengurangi pekerjaan kita, pada penjelasan tambahan yang terbaik. Jawaban analis untuk 'mengapa?' tidak akan perlu menghilangkan anggota, tetapi akan lebih memberi kontribusi ketika situasinya dan penjelasan melebihi bahwa anggota secara konvensonal menemukan kepuasan.

tentang berbedaan antara penyelidikan menentukan observasi sama dengan praktek wawancara. Ketika kita membuat catatan atas apa yang terjadi dalam waktu dan tempat biasa, mendeskripsikan 'bagaimana' adalah beralasan jika tidak penuh secara objektif. Data yang dihasilkan melalui observasi di lokasi dan mendiskripsikan bagamana orang bekerja, bagaimana mereka melakukan kejahatan, bagaimana mereka berjuang dengan pasangan mereka dalam hubungan domestik. Tetapi pertanyaan tentang 'why' orang bertindak sebagaimana mereka melakukan secara logis memerlukan observasi pada waktu yang berbeda: dua peristiwa pada kedua dapat dianggap sebagai hasil dari waktu pertama; dan ini semuanya menyangkut observasi pada tempat yang berbeda agar kekhususan ciriciri dalam situasi biasa yang bermakna dan diambil dalam laporan oleh aktor sebagai kemungkinan perilakunya. Ketika etnografer mengklaim untuk melihat mengapa orang bertindak sebagai apa yang mereka lakukan tanpa menawarkan data dan analisis komparatif, mereka mudah diserang tuduhan bahwa mereka memohon kekuatan magis untuk "melihat ke dalam pikiran" subjek mereka, atau khotbah untuk paduan suara dengan menerapkan pra perangkat rumusan penjelasan yang mereka anggap secara sentimental akan menerima simpati pembaca.

Menurut Katz selanjutnya ada tujuh perangkat syarat evaluasi secara umum digunakan dalam mereview laporan penelitian etnografi. Yang mendasari tiap perangkat sebuah perbedaan terhadap penjelasan dari 'bagaimana' ke 'mengapa'.

1. Secara efektif data memberikan sebuah penjelasan ketika data berkaitan dengan hal yang membingungkan, hal yang berlawanan, atau kemustahilan.

2. Data diapresiasi sebagai strategi paling sedikit pada dua cara yang dapat membuat lintasan data bernilai secara khusus. Perangkat data mungkin terbagi dalam dua bagian di mana setiap data secara ekplisit mendukung pengajuan penjelasan juga secara implisit meniadakan sebuah penjelasan alternatif utama..

3. Data yang kaya dan bervariasi membantu mengatur hipotesis yang berlawanan dengan mengkhususkan definisi penjelasan masalah-masalah dan jawaban-jawaban yang memenuhi syarat.

4. Data yang diteliti membuka pikiran ketika dia menunjukkan bagaimana kekuatan yang membentuk kehidupan sosial secara rutin diabaikan, tersembunyi, atau tidak terlihat.

5. Situasi data menunjuk pada kondisi menengahi yang menentukan apakah secara tetap memberikan kemungkinan akan dimobilisasi.

6. Ketika deskripsi data perilaku dianalisis dalam cara yang secara berbeda estetis, penuh warna, atau hidup, karakteristik keras kepala mereka dari lingkungan sosial, dan menunjuk pada kekuatan yang membentuk pola-pola sosial.

7. Ketika data mendiskripsikan momen yang tajam, dia menangkap orang secara sederhana dengan perhatian lebih pada pola-pola keberlangsungan struktur dalam kehidupan mereka.

Menurut Katz dengan menyampaikan keterlibatan dalam dunia subjek, deskripsi etnografi memecahkan masalah metodologi yang kabur. Pada satu sisi etnografi harus menawarkan penjelasanpenjelasan (eksplanasi) atau akan menjadi sasaran kritik bahwa mereka hanya deskriptif. Beberapa upaya untuk memberikan penjelasan kausal beberapa saran dalam satu pengerti atau yang lain 
adalah apa yang menarik dan mendorong orang, adalah secara umum melalui kebutuhan untuk membuat teks yang menarik perhatian, bahkan mungkin berhubungan secara logis. Dengan kata lain etnografer menghindari penjelasan deterministik, dan untuk metodologi tidak diperlukan alasan-alasan filosofis. Etnografer sering secara personal percaya bahwa faktor-faktor kelas sosial, kepercayaan, etnisitas, atau gender menjelaskan mengapa orang bertindak atau berbuat. Masalah yang mereka temukan adalah data etnografi yang baik tidak pernah menunjukkan sebab-sebab secara langsung, kecuali peneliti secara sistematis membuang kasus-kasus.

Katz memberikan contoh kasuskasus etnografi bagaimana peneliti mendeskripsikan dan mengeksplanasikan. Salah satu contoh kasus di sini adalah seperti penelitian Unni Wikan (1996) yang melakukan kajian tentang perempuan miskin di Kairo berkaitan dengan tuntutan seksual oleh suami mereka. Wikan menjelaskan ciuman dan kepedulian fisik tidak dimiliki di sini - paling tidak diantara masyarakat miskin - . Umm Ali telah memiliki sembilan anak "melalui sentuhan fisik yang sederhana" dengan suaminya Mustafa, sering ingin menolak tetapi ketika dia bercerita pada seorang temannya, temannya mengatakan "kamu harus tidur dengan dia, kamu harus memberinya hak, itu tertulis dalam AI Quran.

Wikan melaporkan satu kali Umm Ali menolak, Mustafa memukulnya dan berteriak "kamu tidak dapat menolak hak saya". Itu adalah dramatik dan tentu saja tidak terlupakan, dan banyak pembaca akan mengidentifikasi sebagai korban, mungkin bahkan dirasakan oleh orang lain dalam kepedihan dan kemarahan.

Penjelasan atau eksplanasi bahwa Islam, orang Mesir, kemiskinan, atau kebudayaan laki-laki yang dominan membentuk pengalaman perempuan di sini secara efektif membuat perbedaan yang amat kecil melalui ironi dalam kejadian ini. Kita belajar bahwa Umm Ali sendiri yang mengacu pada budaya agama, didesak oleh sahabatnya untuk mematuhi suaminya. Dominasi gender tidak bekerja dalam sebuah garis lurus sederhana. Sumbersumber yang ditemukan perempuan untuk menolak datang dari budaya yang dianggap sangat menindasnya. Respon-respon kompleks dan kreatif dari Umm Ali tidak merusak penjelasan bahwa kebudayaan dan tekanan gender membentuk kehidupan sexnya.

\section{b. Ember dan Ember: Asosiasi- asosiasi dan Teori-Teori}

E mber dan Ember (2007:247-248) menjelaskan antropolog di lapangan mencoba untuk sampai pada jawaban yang tepat dari pertanyaan-pertanyaan deskriptif. Bagaimana orang menjalankan kehidupan ? Bagaimana mereka menikah ? Dewa-dewa apa yang mereka percayai ?. Tetapi bagaimanapun pentingnya deskripsi yang akurat itu bukanlah akhir dari tujuan antropologi. Antropolog ingin memahami dan mengetahui mengapa orang memiliki adat istiadat dan kepercayaan tertentu tidak hanya melihat apa yang mereka punyai. Menjawab pertanyaan bagaimana dan apa sama-sama sulit tetapi lebih sulit menjawab pertanyaan mengapa. Pertanyaan mengapa berkaitan dengan eksplanasi atau penjelasan, yang lebih sulit untuk dihasilkan dan untuk dievaluasi. Dalam ilmu pengetahuan untuk mengerti adalah dengan menjelaskan, dan juga tujuan utama dari ilmu pengetahuan adalah untuk sampai pada penjelasan yang dapat dipercaya.

Untuk banyak antropolog keadaan yang dapat diterima atau mampu meyakinkannya sebuah eksplanasi tidak dapat dianggap sebuah alasan yang cukup untuk diterima. Eksplanasi harus juga diuji dan didukung oleh fakta-fakta objektif yang masuk akal. Menurut orientasi yang berdasarkan ilmu pengetahuan semua pengetahuan tidak pasti karena itu subjek untuk konfirmasi menaikkan atau menurunkan sebagai tes baru dibuat. Jika ini benar - dan mungkin tidak cukup menyenangkan untuk diakui - itu berarti bahwa kita tidak akan pernah sampai pada kebenaran absolute. Pada sisi lain dan ini adalah mendorong kita harus dapat mencapai pemahaman yang lebih dapat dipercaya jika kita menguji teori-teori kita.

Sebuah eksplanasi adalah sebuah jawaban untuk pertanyaan mengapa. Ada banyak tipe eksplanasi beberapa lebih memuaskan dari yang lain.Sebagai contoh misalkan kita menanyakan mengapa sebuah masyarakat mempunyai pantangan 
berhubungan sex yang lama setelah melahirkan. Kita dapat memperkirakan bahwa orang dalam masyarakat itu ingin pantang berhubungan sex untuk satu tahun mulai setelah melahirkan bayi. Apakah ini sebuah penjelasan ? ya karena ini menjelaskan mengapa orang mempraktekkan adat istiadat, tetapi penjelasan seperti ini tidak memuaskan karena tidak menjelaskan secara spesifik apa tujuan dari adat istiadat itu. Bagaimana tentang ide bahwa orang-orang mempunyai pantangan sex yang lama itu adalah disebabkan oleh tradisi mereka? Ya itu juga sebuah eksplanasi, tetapi tidak memuaskan untuk alas an yang berbeda. Itu adalah sebuah tautology yaitu hal yang akan diterangkan (pantangan itu) adalah dijelaskan oleh dirinya sendiri, oleh keberadaan sebelumnya. Untuk menerangkan sesuatu dalam istilah tradisi adalah untuk mengatakan bahwa orang melakukannya karena mereka telah melakukannya sebelumnya ini adalah tidak informative. Jenis eksplanasi apa yang lebih memuaskan kemudian, ada dua jenis eksplanasi dimana peneliti mencoba untuk melakukannya: asosiasi-asosiasi dan teoriteori.

Asosiasi-asosiasi, satu cara menerangkan sesuatu (sebuah observasi, sebuah tindakan, sebuah adat istiadat) adalah bagaimana dia sesusai dengan prinsip umum atau relationship. Jadi untuk menjelaskan mengapa air ditinggalkan di baskom di luar membeku, kita katakan malam tadi dingin dan air membeku pada 32 derajat $F$. Pernyataan bahwa air menjadi es pada 32 derjat $F$ adalah sebuah pernyataan dari hubungan asosiasi antara dua variable - hal yang kuantitasnya beragam. Kebenaran dari hubungan ditunjukkan oleh observasi yang berulang. Dalam ilmu fisika hubungan itu disebut hukum ketika diterima oleh hamper semua ilmuwan,

Dalam ilmu sosial asosiasi-asosiasi biasanya dinyatakan secara kemungkinan, adalah yang kita katakan dua atau lebih variable cenderung menjadi berhubungan dalam sebuah cara yang dapat diprediksi, yang berarti bahwa ada biasanya beberapa kekecualian. Sebagai contoh untuk menerangkan mengapa mengapa suatu masyarakat mempunyai masa lama berpantangnan sex, kita dapat menunjukkan asosiasi atau korelasi yang ditemukan oleh
John Whiting dalam sebuah sampel masyarakat-mayarakat di dunia. Masyarakat dengan jelas yang rendah diet protein cendrung mempunyai pantangan sex yang lama setelah melahirkan. Kita menyebut hubungan antara diet protein rendah dan pantangan sex sebuah asosiasi statistik, yang berarti bahwa hubungan yang diobservasi adalah tidak mungkin diterima untuk kesempatan.

Teori-teori. - penjelasan-penjelasan asosiasi hukum dan statistic - lebih kompleks dari hubungan observasi yang bertujuan untuk menerangkan. Adalah sulit untuk menjelaskan secara tepat apa itu teori. Mari kita kembali pada pertanyaan mengapa beberapa masyarakat mempunyai masa panjang berpantangan sex. Kita telah melihat sebuah asosiasi statistic dapat digunakan untuk menerangkannya. Secara umum jika suatu masyarakat mempunyai diet rendah protein itu akan mempunyai pantangan yang lama. Tetapi banyak orang akan bertanya pertanyaan tambahan: Mengapa diet rendah protein menerangkan pantangan ? . Aapakah mekanisme di mana sebuah masyarakat dengan semacam diet mengembangkan tradisi sex taboo yang lama ? Sebuah teori dapat menjawab pertanyaan tersebut.

Teori John Whiting bahwa pantangan lama sex setelah melahirkan mungkin sebuah adaptasi terhadap kondisi tertentu. Khususnya di daerah tropis di mana makanan utama adalah rendah protein, bayi mudah mengalami penyakit kekurangan protein yang dinamakan kwashiorkor. Tetapi jika bayi bisa dirawat dalam waktu yang lama mungkin lebih ada kesempatan untuk survive. Pantangan sex yang lama setelah melahirkan mungkin adaptif. Teori Whiting menunjukkan karena berkembangnya kemungkinan bayi yang survive. Adalah jika seorang ibu berhenti melahirkan untuk sementara, bayi yang pertama mungkin mempunyai kesempatan yang lebih baik untuk survive karena dapat disusui oleh ibunya untuk waktu yang lama. Whiting menunjukkan bahwa orang tua mungkin sadar, apakah disadari atau tidak disadari, bahwa mempunyai bayi yang lain terlalu cepat dapat merusak kelangsungan hidup bayi pertama, dan juga mereka mungkin memutuskan itu akan menjadi gagasan yang baik untuk berhenti 
berhubungan untuk lebih dari satu tahun setelah kelahiran anak pertama.

\section{Beberapa Contoh Deskripsi dan Eksplanasi Dalam Kasus-Kasus Etnografi}

\section{Margaret Mead dan Gejolak Masa Pubertas}

argaret Mead melakukan penelitian di Samoa tentang pubertas remaja pada tahun 1920-an. Mead tertarik mengkaji hubungan antara psikologi dan kebudayaan, pada waktu itu konsep tentang "gejolak pada masa pubertas" dianggap sebagai gejala psikologis yang berlaku universal. Artinya apabila seseorang memasuki usia remaja secara psikologis dia akan mengalami perubahan prilaku seperti suka menentang orang tua, sukar diatur, dan ketegangan-ketegangan psikologis lainnya. Mead melakukan penelitian di Samoa selama kurang lebih sebelas bulan, dia bergaul dengan orang-orang Samoa dan juga remajanya, melakukan observasi dan wawancara mendalam.

Dalam bukunya yang dia buat sebagai hasil penelitian tersebut dia mendeskripsikan dengan jelas kehidupan sehari-hari remaja Samoa. Kehidupan remaja Samoa dalam hubungan antara lakilaki dan perempuan tergolong bebas. Mead juga menggambarkan hubungan-hubungan yang harmonis dalam keluarga luas. Seorang anak tidak hanya dekat dengan ayah, ibu atau saudara-saudara kandungnya tetapi juga dengan kerabatkerabat yang lain seperti kakek, nenek, paman, bibi, dan saudara-saudara sepupunya. Mead tidak menemukan gejolak pada masa pubertas pada remaja Samoa. Mead menjelaskan (memberikan eksplanasi) mengapa tidak ada Gejolak pubertas di Samoa adalah karena kebudayaan Samoa yang lebih tidak menerapkan aturan-aturan yang ketat pada pergaulan remaja dan kontrol keluarga inti yang tidak dominan pada seorang anak atau remaja ini membuat remaja secara emosional lebih stabil.

\section{Margaret Mead dan Gender}

$\mathrm{M}$ ead melakukan penelitian pada tiga kebudayaan di lembah sungai Sevik di Papua New Guenia. Tujuan penelitiannya juga hampir sama dengan penelitian tentang masa pubertas remaja di atas. Mead ingin menguji pandangan bahwa sex dan gender adalah berkaitan dengan biologi karena itu perbedaan gender itu berlaku universal dan artinya variasi kebudayaan tidak signifikan.

Penelitiannnya di Papua New Guenia menemukan variasi kebudayaan tidak keseragaman kebudayaan tentang gender. Dia menemukan bahwa perempuan di Arapesh sama dengan perempuan di Amerika Serikat, secara umum lembut, pengasuh, dan tidak kasar dan yang mengejutkan laki-laki menunjukkan ciri-ciri yang sama dengan perempuan, keras dan agresif dianggap sebagai perilaku yang tidak dapat diterima. Masyarakat Mundugumor mirip dengan Arapesh dalam arti tidak dapat dijelaskan perbedaan laki-laki dan perempuan tetapi dengan ciri-ciri dominan yang berbalikan dengan Arapesh, dalam masyarakat ini laki-laki dan perempuan sama-sama keras, tipikal laki-laki macho yaitu agresif dan keras. Dalam masyarakat Tchambuli Mead menemukan perbedaan peran sex, perempuan lebih dominan secara sexual dan bertanggung jawab akan keberlangsungan rumah tangga dan menyediakan makanan untuk keluarga. Laki-laki sebaliknya memberikan sumbangan yang sangat sedikit pada ekonomi rumah tangga.

Hasil kajian lapangan ini dijelaskan (dieksplanasikan) oleh Margaret Mead bahwa perbedaan peran antara laki-laki dan perempuan yang dianggap sebagai akibat dari interaksi antara psikologis dan biologis karena itu dianggap universal tidak benar. Kebudayaan lebih menentukan perbedaan peran antara perempuan dan laki-laki.

Eksplanasi yang dilakukan oleh Margaret Mead untuk kedua kasus kajiannya tersebut kelihatannya lebih kepada kajian eksplanasi kausal atau asosiasi-asosiasi menurut istilah Ember dan Ember. Di mana Mead dalam kajiannya tentang pubertas menjelaskan eksplanasi dari hubungan fakta-fakta yang dia temukan di lapangan seperti betuk keluarga luas dan pergaulan reaja yang agak bebas. 
Kemudian juga dalam kajian tentang gender Mead menguhubungkan fakta-fakta di lapangan di tiga suku bangsa yang berbeda dan menghubungkannya untuk menjelaskan peran laki-laki dan perempuan lebih ditentukan oleh kebudayaan dari pada faktor biologis.

\section{Malinowski dan Sistem Kula}

$\mathrm{M}$ alinowski

(dalam

Kontjaraningrat, 1980:164-165)

apangan hasil penelitan menghasilkan buku yang berjudul Argonauts of the Western Pacifics (1922) melukiskan suatu system perdagangan antara penduduk kepulauan Trobriand yang terdiri dari banyak pulau-pulau kecil yang semuanya terletak di sebelah Timur Papua New Guenia. Dengan hanya perahu-perahu bercadik dan dengan awak kapal yang berjumlah sepuluh hingga lima belas orang, penduduk kepulauan Trobriand tersebut berani menyebrangi laut terbuka untuk berlayar dari pulau ke pulau sampai beratesratus mil jauhnya. Benda-benda yang diperdagangkan dengan jalan tukar menukar (barter) berupa berbagai macam bahan makanan, barang-barang kerajinan, alat-alat perikanan, perkebunan, dan rumah tangga, tetapi disamping itu pada tiap transaksi diadakan tukar menukar dua macam benda perhiasan yang dianggap mempunyai nilai yang sangat tinggi, yaitu kalung-kalung kerang (sulava) yang beredar ke satu arah mengikuti arah jarum jam, dan gelang-gelang kerang (mwali) yang beredar kearah yang berlawanan. Sistem perdangangan tersebut disebut dengan system kula.

Hal yang sangat menarik adalah cara menggambarkan hubungan terkait antara system kula dengan lingkungan alam sekitar pulau-pulau serta berbagai macam unsur-unsur kebudayaan dan masyarakat penduduknya yaitu ciri-ciri fisik dari lingkungan alam setiap pulau, keindahan lautnya, aneka warna floranya, pola-pola pemukiman komunitas serta kebunkebunnya, arti lingkungan alam bagi pulaupulau untuk membuat perahu, serta barangbarang yang diperdangangkan dalam kula, system kekerabatan serta laitannya dalam kerja sama system kula, system pimpinan desa dan pimpinan kula, system pemilikan perahu serta cara-cara pengerahan tenaga atau awak kapal untuk kula. Bahan-bahan keterangan tersebut diuraikan dengan gaya bahasa yang sangat lancar dan memikat, sehingga seluruh kehidupan masyarakat desa Trobriand itu tampak terbayang di depan mata kita sebagai suatu sistem sosial yang berinteraksi secara fungsional.

Malinowski secara tidak langsung dalam deskripsinya telah mengaitkan dengan eksplanasi yaitu menghubungkan lingkungan dan aktifitas-aktifitas masyarakat sebagai sistem sosial yang saling terkait secara fungsional. Inti teori fungsional Malinowski adalah bahwa segala aktifitas kebudayaan itu sebenarnya bermaksud untuk memuaskan suatu rangkaian dari sejumlah kebutuhan naluri manusia yang berhubungan dengan seluruh kehidupannya.

\section{Keluarga Jawa Hildred Geertz}

$\mathrm{H}$ ildred Geertz melakukan penelitian tentang system kekerabatan Jawa pada tahun 1950-an yang kemudian melahirkan buku dengan judul The Javanase Family yang kemudian diterjemahkan ke bahasa Indonesia dengan judul Keluarga Jawa. Dalam pengantar buku ini Koentajaraningrat menyebut buku ini merupakan kajian antropologi mengenai das Sein dari kehidupan kekerabatan orang Jawa di suatu kota kecil di Jawa Timur kecuali merupakan deskripsi yang cukup jelas dan baik mengenai fungsi sistem kekerabatan Jawa dalam kehidupan seharihari, buku ini juga memberi suatu gambaran yang jelas mengenai pembentukan dan perkembangan sikap mental dan orientasi orang Jawa pada umumnya di dalam proses sosialisasinya melalui adat istiadat pengasuhan anak dalam keluarga.

Buku ini secara panjang lebar menguraikan secara deskriptif sistem kekerabatan Jawa berdasarkan penelitian observasi partisipasi yang dilakukan oleh Hildred Geertz. Bab dua buku yang berjudul struktur sistem pertalian keluarga Jawa menguraikan tentang terminologi sistem pertalian keluarga, tentang keluarga sedarah dan keluarga perbesanan, komposisi rumah tangga, pembagian harta pada perceraian dan pada kematian, 
perkawinan dan struktur pertalian keluarga Jawa. Sedangkan Bab tiga dengan judul bekerjanya system pertalian Jawa menguraikan tentang adat kehamilan dan kelahiran, mengasuh dan melatih bayi, hubungan sosial dalam masa kanak-kanak, masa remaja, masa dewasa, dan nilai-nilai kejawen dalam keluarga orang Jawa. Bab dua dan Bab tiga boleh dikatakan sebagai bagian deskripsi dari buku ini yaitu menjelaskan tentang bagaimana (how). Eksplanasi atau menjelaskan tentang mengapa (why) dalam buku ini ada di Bab satu, eksplanasi yang kalau merujuk pada Ember dan Ember lebih kepada eksplanasi berdasarkan asosiasi-asosiasi atau relasionsip bukan berdasarkan teori-teori. Geertz menguraikan eksplanasi pada Bab satu seperti yang digambarkan pada alinea berikut.

Jawa telah memeluk peradaban kota sekurang-kurangnya selama seribu lima ratus tahun. Mayoritas penduduk petani yang tinggal di desa-desa tetapi desa mereka terletak tidak jauh dari kota dan sangat banyak orang kota yang lahir di desa. Cara hidup kota dengan demikian bukanlah asing bagi setiap orang Jawa manapun.

Dalam hubungan ini mudah dipahami jika pertalian keluarga dengan ikatan-ikatan sosialnya yang ketat, khas dan askriptif itu hanya memainkan peran sekunder dalam struktur Jawa secara keseluruhan bertentangan dengan peranan sebagai poros yang dimainkan oleh pertalian keluarga itu dalam masyarakat tradisional dalam membangun kekuatan ekonomi, politik, dan bahkan keagamaan. Tegasnya dari sudut pandang bekerjanya bekerjanya masyarakat pertalian keluarga Jawa yang secara timbal balik dengan somah - keluarga inti - sebagai kelompok kelompok pertalian keluarga yang terpenting itu bagaimanapun memberi sumbangan sekadarnya.

Tetapi sumbangan yang sedikit itu sangat penting artinya bagi ketenangan dan kesinambungan masyarakat Jawa dalam bentuknya seperti sekarang ini. Tercakup di dalamnya sarana bagi golongan yang menderita tersebut. Di dalamnya kebutuhan pribadi, ekonomi, sosial, dan psikologis para anggota masyarakat terpenuhi, dan nilai-nilai social di wariskan dan dikukuhkan.
Masalah pokok dari telaah Geertz adalah bagaimana dua fungsi poros itu ditunaikan dalam keluarga Jawa. Kemudian yang menjadi perhatian adalah masalah proses sosialisasi - pemeliharaan kontinuitas normativ dari generasi ke generasi. Karena beberapa nilai ke Jawaan yang paling terserap itu dipertahankan tidak saja melalui cara-cara sosialisasi yang ditempuh oleh orang-orang tua Jawa atas anak-anak mereka melainkan melalui struktur pertalian kekeluargaan itu sendiri.

Somah merupakan satu-satunya unit pertalian kekeluargaan yang penting. Sanak kadang lainnya tidak terorganisasi dalam suatu macam kelompok bersama apapun, dan teristimewa pula tidak berfungsi sebagai sumber-sumber bantuan dalam kesusahan serta sumber persaudaraan yang membahagiakan. Somah tersebut dijalin dengan rapat, terkadang diperkukuh oleh seorang atau dua orang sanak saudara yang bertindak selaku wujud kesatuan dalam hubungan dengan somah-somah yang berdekatan dan dengan somah sanak saudara lainnya. Dalam kehidupan kampong halaman bukanlah anggota-anggota secara perorangan tetapi somah itulah yang bertindak dalam masalah-masalah sangat penting, adakalanya mungkin suami atau mungkin pula istri yang akan bertindak selaku wakil somah sebagai keseluruhan. Sang suami dalam hal-hal ritual dan sang istri dalam peristiwa tertentu, misalnya perkawinan dan kelahiran. Setiap kelompok somah tampil dihadapan kelompok somah lainnya sebagai suatu unit social, misalnya dalam hal pinjam meminjam tenaga kerja, pengakuan terhadap kedudukan social, serta partisipasi social mereka umumnya. Dari sudut ekonomi rumah tangga somah itu merupakan kelompok konsumsi dasar.

Tiap-tiap anggota somah - bahkan anak-anak - memiliki hak atas miliknya sendiri, namun segala yang masuk ke dalam rumah tangga itu biasanya dibagi lagi diantara para anggota menurut kebutuhan. Bagaimanapun rumah tangga somah jarang merupakan suatu unit produksi yang lengkap. Hal ini benar bahkan di kalangan petani , yaitu karena pertanian padi yang mengharuskan ikut sertanya tenaga kerja manusia dalam jumlah yang lebih besar dan tidak tertanggulangi oleh somah belaka. 
Tanah dimiliki atau dikuasai oleh perseorangan. Sanak kadang seseorang yang bukan saudara terdekatnya, dibanding tetangga sekitar masih mempunyai hak barang sedikit atas penggunaan tanah itu atau bekerja di tanah itu. Malah orang kota mempunyai ikatan yang lebih tipis dengan sanak kadang mereka apabila dibandingkan dengan para petani, yaitu karena secara perseorangan mereka umumnya bekerja sebagai pegawai negri atau dalam dunia perdagangan. Bahkan orang kota yang berwiraswasta, misalnya seseorang dengan pabrik rokok kecil, tidak mengelola perusahaannya tersebut dalam bentuk sebuah usaha keluarga melainkan mempekerjakan orang luar sebagaimana halnya terhadap anggota keluarga sendiri.

Di samping tugas-tugas ritual dan ekonomi serta sosialisasi anak, rumah tangga somah tersebut juga menjalankan tugasnya yang lain. Yaitu mengurus para anggota keluarga yang tidak dapat mengurus dirinya sendiri - sakit, menganggur, umur tua, yatim piatu. Mereka ini diserap ke dalam somah sanak kadangnya yang terdekat dan kebutuhan mereka di urus. Aspek jaminan social dalam keluarga ini merupakan hal yang penting untuk bekerjanya masyarakat Jawa sebagai suatu keseluruhan. la memberi ukuran kepatutan dan keluwesan bagi masyarakat karena ia memberi gerak keluar masuk penampungan tenaga kerja tanpa mengganggu lembaga-lembaga lain dalam masyarakat itu. Namun banyaknya bantuan sebenarnya dari lembaga-lembaga tertentu di luar somah hendaknya tidak di lebihlebihkan. Setiap keluarga mempunyai suatu hak moral untuk mendapatkan bantuan dalam saat-saat sulit, namun daya kekuatan hak tersebut cepat melarut bersamaan dengan hak pertaliannya.

Bagi seorang Jawa ikatan keluarga hanyalah sebuah unsur di antara yang banyak - misalnya kedudukan , umur, dan kekayaan - yang memberikannya batasanbatasan dalam hubungan seseorang dengan orang lain. Sesungguhnya ciri terpenting dalam pandangan Jawa tentang inkataan kekeluargaan itu adalah banyaknya kebebasan bertindak yang terbuka bagi seseorang. Dalam situasi sosial tertentu ikatan kekeluargaan hanyalah sebuah faktor diantara banyak faktor yang dapat berpengaruh terhadap tingkah laku seseorang. Misalnya jika terdapat perbedaan kekayaan yang besar diantara dua bersaudara, atau benturan pribadi diantara mereka, atau jarak geografis kediaman yang tidak menentu, mereka dapat mengabaikan pertalian kekeluargaan tersebut atau dapat juga member arti menurut kehendak sendiri sejalan dengan tuntutan situasi tertentu mereka.

Kemungkinan manipulasi atas ikatan kekeluargaan tersebut dalam praktek berhubungan dengan tabiat system kekeluargaan itu sendiri - anggapan remeh terhadap referensi, tidak adanya kelompok social yang berdasarkan keluarga, dan lebih lanjut kelemahan kekaburan, dan keterbatasan jumlah kaidah-kaidah hokum dari padanya, hak-hak serta kewajiban diantara keluarga itu. Bahkan diantara orang tua dan anak-anakpun hak dan kewajiban kekeluargaan itu diberikan dengan kebebasan penafsiran perorangan. Pemindahan hak milik pada perceraian atau kematian biasanya diselesaikan dengan tidak terlalu banyak bergantung pada aturan-aturan hokum yang abstrak, melainkan sesuai dengan situasi tertentu dan dengan keadilan yang lebih hakiki sambil mempertimbangkan kepentingan pribadi-pribadi yang terlibat.

Tidak terdapat pola perkawinan yang lebih diutamakan , pemilihan pasangan hidup menjadi masalah pribadi dan keluarga terdekatnya. Apa yang disebutkan mengenai kemungkinan manipulasi atas ikatan kekeluargaan tidak sepenuhnya berarti suatu pengubahan dan pengaturan kembali atas penggolongan kekeluargaan atas seseorang agar sesuai dengan kehendak sendiri karena kurangnya unsure kekerasan di dalam penggolongan-penggolongan kekeluargaan itu sendiri, melainkan suatu toleransi yang membuat lebih gampang untuk menghindar dari tanggung jawab kekeluargaan serta mempersempit jarak pertalian kekeluargaan yang efektif.

Di mata orang Jawa setiap anggota keluarga merupakan suatu pribadi yang tunggal. Bagaimana ia akan bersikap terhadap anggota keluarga ini merupakan fungsi dari sekurang-kurangnya enam faktor yang berbeda-beda:seks, umur, posisi kelas, pandangan ideology keagamaan, perasaan pribadi, dan pertalian kekeluargaan. Di luar lingkaran keluarga terdekat, unsur pertalian kekeluargaan tersebut sering merupakan 
faktor yang terlemah diantara enam faktor tersebut.

Kendati demikian bagi setiap orang Jawa, keluarga - yaitu orang tua, anakanak, biasanya suami atau istri - merupakan orang yang terpenting di dunia ini. Mereka itulah yang memberikan kepadanya kesejahteraan emosional serta titik keseimbangan dalam orientasi sosial. Mereka memberi bimbingan moral, membantunya dari masa kanak-kanak menempuh usia tua dengan mempelajari nilai-nilai budaya Jawa. Proses sosialisasi adalah suatu proses bersinambungan di sepanjang hidup diri pribadi. Saudarasaudara terdekat orang itulah yang dengan tegur sapanya dari hari ke hari baik yang terucapkan maupun yang tidak terucapkan , menjaganya dari terlampau jauh meninggalkan rel kaidah-kaidah budaya.

\section{Kisah Lima Keluarga Oscar Lewis}

$\mathrm{B}$ uku ini adalah buku etnografi tentang kisah lima keluarga miskin di ibu kota Meksiko. Oscar Lewis ingin menggambarkan kehidupan masyarakat yang sebelumnya jarang disentuh oleh ahli antropologi yaitu masyarakat miskin pedesaan dan perkotaan, sedangkan sebelumnya antropolog lebih banyak mengkaji masyarakat bisa dikatakan primitif atau terasing. Buku ini lebih banyak menjelaskan secara deskriptif kehidupan keluarga miskin tersebut berdasarkan pengamatan partisipasi yang mendalam dan lama. Oscar Lewis mendeskripsikan secara terpisah masing-masing kehidupan keluarga miskin tersebut dengan menggambarkan seolah-olah kehidupan satu hari masingmasing keluarga tersebut. Pemilihan satu hari sebagai unit penelitian menurut Oscar Lewis biasa dilakukan oleh seorang pengarang novel, tetapi hal ini jarang digunakan dan tidak pernah dimanfaatkan oleh seorang antropolog. Tetapi yang pasti buku ini lebih banyak menjelaskan tentang bagaimana (how) kehidupan orang miskin tersebut.

Telaahannya tentang sehari dalam kehidupan dari masing-masing lima keluarga Meksiko itu merupakan suatu usaha untuk memberikan suatu gambaran hidup dari sebuah kelompok umat manusia yang berjuta-juta itu melalui proses percontohan secara mendalam. Caranya hampir sama objektifnya seperti kebanyakan kerja lapangan etnologis. Oscar Lewis tidak menunjukkan suatu moral, tidak menarik kesimpulan, kecuali dalam bagian pembukaannya terpisah dan dengan sangat terkendali tidak memberi komentar. la hanya menguraikan di hadapan kita lima hari yang luar biasa dalam kehidupan lima keluarga sederhana yang representative itu.

Menurut Parsudi Suparlan dalam kata pengantar buku ini Oscar Lewis menunjukkan kemampuannya dalam menggambarkan kehidupan masyarakat yang ditulisnya sehingga tampak dekat sekali dan seolah-olah hidup dalam imaji pembacanya. Dia mampu mengungkapkan perasaan-perasaan, emosi-emosi dan imajiimaji para pelakunya sebagai suatu yang benar-benar hidup sehingga pembacanya merasa terlibat di dalam adegan-adegan peristiwa-peristiwanya. Tulisannya tidak hanya bermutu secara teknis ilmiah antropologi tetapi juga sebagai karya sastra yang enak dibaca dan sebagai bacaan umum yang mengungkapkan dari kehidupan manusiawi yang sehari-harinya tampak samar-samar tetapi tetap ada dalam kehidupan manusia. Ungkapanungkapannya plastis tetapi tidak cengeng, begitu juga tidak agitatif atau sok menggurui, yang menyebabkan buku ini mendapat sambutan luas di kalangan pembaca bukan ahli antropologi di Amerika Serikat.

Parsudi Suparlan selanjutnya menjelaskan metode yang digunakan dalam mengumpulkan data adalah metode etnografi, yaitu yang menekankan metode observasi partisipasi untuk dapat menggambarkan kebudayaan masyarakat yang ditelitinya, dengan identitas yang jelas untuk mempelajari guna memahami dan turut menggunakan ungkapan-ungkapan yang mereka gunakan dalam kehidupan sehari-hari, baik yang terus terang dan jelas maupun yang tersamar. Sehingga ungkapan-ungkapan emosi dan perasaan imaji dan harapan-harapan kasih saying dan kebencian keberanian dan ketakutan serta kehidupan sehari-hari dapat dipahami dan masuk akal bagi si peneliti sesuai dengan logika yang berlaku dalam kebudayaan masyarakat yang diteliti. Jadi dalam metode observasi papartisipasi tidak digunakan 'alat pengukuran objektif' yang biasa digunakan dalam penelitian yang menggunakan 
pendekatan kuantitatif. Tujuan penelitian kuantitatif adalah mengukur gejala-gejala. Sedangkan penelitian kualitatif seperti yang dilakukan Oscar Lewis adalah mendeskripsikan pola-pola dan systemsistem makna kebudayaan yang mendasari dan member pedoman bagi tindakantindakan warga masyarakat yang bersangkutan.

Oscar Lewis tidak melihat masalah kemiskinan sebagai masalah ekonomi yaitu tidak dikuasainya sumber-sumber produksi dan distribusi benda-benda dan jasa ekonomi oleh orang miskin, tidak juga melihatnya secara makro yaitu dalam kerangka teori ketergantungan antar Negara atau antar satuan produksi dan masyarakat dan tidak juga melihatnya sebagai pertentangan kelas sebagaimana yang dikembangkan oleh ilmuwan social Marxis. Oscar Lewis melihat kemiskinan sebagai cara hidup atau kebudayaan dan unit sasarannya adalah mikro, yaitu keluarga karena keluarga dilihat sebagai satuan social terkecil dan sebagai pranata sosial pendukung kebudayaan kemiskinan. Kemiskinan menjadi lestari di dalam masyarakat yang berkebudayaan kemiskinan karena pola-pola sosialisasi yang sebagian terbesar berlaku dalam kehidupan keluarga. Pola-pola sosialisasi yang berlandaskan pada kebudayaannya yang berfungsi sebagai mekanisme adaptif terhadap kemiskinan yang dihadapi seharihari.

Dalam buku ini Oscar Lewis berusaha memberikan suatu gambaran kepada pembaca tentang kehidupan seharihari dari lima keluarga Meksiko, empat diantaranya termasuk kelompok berpenghasilan rendah. Tujuan penulisan buku ini adalah untuk menyumbang kepada pengertian tentang kebudayaan kemiskinan di Meksiko sekarang dan sejauh orangorang miskin di seluruh dunia mempunyai persamaan dengan kehidupan tingkat rendah pada umumnya.

Ada lima keluarga yang digambarkan dalam buku ini pertama adalah keluarga Pedro Martinez, keluarga yang hidup untung menyambung hidup belaka. Mereka tinggal di sebuah desa enam mil di sebelah selatan Mexico City. Dia didampingi istrinya yang mendekati sosok ideal, sederhana, dan patuh. Anak-anak mereka juga memenuhi syarat-syarat norma pedesaan , keras, hormat, dan patuh, walaupun ketika semakin tua mereka mulai berubah sebagai tanggapan terhadap perubahan-perubahan.

Keluarga kedua adalah keluarga dalam masa peralihan dari kehidupan desa ke kehidupan kota yaitu keluarga Agustin Gomez. Keluarga ini berasal dari keluarga petani yang telah tinggal di kota selama 17 tahun. Mereka merupakan keluarga kelas pekerja yang harus mengatasi banyak kesulitan, tinggal dalam sebuah apartemen dengan satu kamar yang penuh sesak dalam sebuah perkampungan kumuh yang disebut dengan istilah vecindad.Keluarga ini tidak banyak memperlihatkan kekacauan dan kerusakan yang sering sekali dihubungan dengan proses urbanisasi dan tetap stabil meskipun terdapat konflik intern.

Keluarga ketiga adalah keluarga Guillermo Gutierrez, keluarga ini tinggal di salah satu perumahan petak yang termiskin di kota. Tetapi keluarga ini menunjukkan penyesuaian yang terbaik terhadap keadaan kehidupannya dan tidak terdapat begitu banyak ketegangan antara suami istri seperti dibandingkan dengan keluargakeluarga lainnya. Guillermo adalah seorang tukang dan kecil-kecilan dan pengusaha took, sedangkan istrinya seorang penjual keliling.

Keluarga keempat adalah keluarga Jesus Sanches yang menurut Oscar Lewis menggabungkan sifat-sifat kelas pekerja dan kelas menengah bawah. Sanchez seorang pekerja restoran yang sejak lama sudah kehilangan hubungannya dengan desa asalnya, menambah penghasilan yang rendah dengan memelihara ayam dan babi. Dia baru memenangkan lotere nasional dia telah membangun rumah di dalam perkampungan miskin di pinggiran kota. Dia memiliki dua orang istri, istri mudanya tinggal di rumah petak di kota.

Keluarga kelima adalah keluarga kaya baru yaitu keluarga David Castro, seorang jutawan yang maju karena usaha sendiri. Castro dibesarkan di rumah petak di perkampungan kumuh yang sama sekali belum kehilangan sifat-sifat kelas bawahnya. Hal ini dapat dilihat dalam hubungan dengan istri dan kekasihnya. Dalam kekasarannya terhadap istri dan anak-anaknya, dalam cara dia meninggalkan mereka pada waktu-waktu tertentu, dalam memberi uang belanja harian kepada istrinya, dan dalam 
memberikan hukuman kepada istrinya dengan tidak memberikan uang belanja.

Oscar Lewis tidak memberikan eksplanasi yang panjang tentang deskripsi etnografinya ini kecuali beberapa poin penting dalam bagian awal bukunya. Menurutnya tujuan menulis buku ini adalah untuk menyumbangkan pengertian tentang kebudayaan kemiskinan di Meksiko dan sejauh orang-orang miskin di seluruh dunia mempunyai persamaan dengan kehidupan tingkat rendah pada umumnya.

Oscar Lewis menjelaskan

kemiskinan pada bangsa-bangsa modern adalah hal yang sangat berbeda. Kemiskinan ini menunjukkan adanya pertentangan kelas, masalah-masalah sosial, dan perlunya perubahan dan hal ini seringkali diartikan demikian oleh subjek penelitian itu. Kemiskinan menjadi suatu faktor dinamis yang mempengaruhi partisipasi dalam kebudayaan nasional yang lebih luas dan menciptakan suatu sub kultur tersendiri. Orang dapat berbicara tentang kebudayaan si miskin, karena kebudayaan tersebut mempunyai cara-cara dan akibatakibat sosial serta psikologis tersendiri bagi para anggotanya. Tampaknya kebudayaan kemiskinan membelah batas-batas regional, pedesaan-kota dan bahkan batas-batas nasional. Misalnya persamaan dalam struktur keluarga, pola hubungan keluarga, pola hubungan suami istri dan orang tua anak, pola pengeluaran, sistem nilai, dan rasa kemasyarakatan.

Dalam buku ini kelihatannya juga Oscar Lewis tidak memberikan eksplanasi teoritis. Dia memberikan eksplanasi dari asosiasi-asosiasi atau relationship antara variable. Oscar Lewis (1988:4) menjelaskan dari fenomena yang dia lihat kemiskinan menunjukkan adanya pertentangan kelas, masalah-masalah sosial, dan perlunya perubahan; dan dalam hal ini sering diartikan demikian oleh subjek penelitian itu. Kemiskinan menjadi faktor dinamis yang mempengaruhi partisipasi dalam kebudayaan nasional yang lebih luas dan menciptakan suatu sub kultur tersediri. Orang dapat berbicara tentang kebudayaan si miskin, karena kebudayaan tersebut mempunyai cara-cara dan akibat-akibat sosial serta psikologis tersendiri bagi para anggotanya. Tampaknya membelah batas- batas regional, pedesaan, kota, bahkan batas-batas nasional. Misalnya oleh persamaan luar biasa dalam struktur keluarga, pola hubungan suami istri, serta orang tua anak, pola pengeluaran, sistem nilai, dan rasa kemasyarakatan yang terdapat di perkampungan kelas bawah di London, di Puerto Rico, di perkampungan kumuh Mexico City, dan desa-desa Meksiko, dan diantara orang-orang negro kelas bawah di Amerika Serikat.

\section{Penutup}

$\mathrm{P}$ ekerjaan seorang antropolog atau etnografer tidak terlepas dari proses deskripsi dan eksplanasi. Tugas ini dapat dikatakan sebagai tugas tahap akhir seorang antropolog dalam proses penelitian. Setelah sekian lama di lapangan melakukan penelitian mulai dari observasi partisipasi, wawancara mendalam, membuat catatan lapangan, dan merumuskannya dalam laporan penelitian. Laporan penelitian ini secara langsung berkaitan dengan deskripsi dan eksplanasi. Deskripsi adalah melukiskan secara deskriptif temuan-temuan penelitian lapangan sesuai dengan tujuan penelitian dalam arti bagaimana (how). Sedangkan eksplanasi adalah penjelasan tentang fenomena dalam arti mengapa (why).

Walaupun deskripsi dan eksplanasi dapat terpisah tetapi keduanya terkait erat. Seorang peneliti dapat melahirkan gambaran deskriptif saja dari hasil penelitiannya tetapi eksplanasi tidak bisa tanpa ada deskripsi. Penelitian deskriptif saja sebenarnya belum bisa dikatakan ilmiah, karena penelitian harus bisa menjelaskan mengapa (why) dari satu fenomena.

Seperti yang telah digambarkan di atas eksplanasi dapat dibedakan menjadi eksplanasi kausal dan eksplanasi teoritis. Eksplanasi kausal menjelas fenomena berdasarkan hubungan asosiasi-asosiasi dari fakta-fakta yang ditemukan di lapangan. Sedangkan eksplanasi teoritis merupakan eksplanasi yang berdasarkan teori juga berarti perspektif. Seperti Geertz eksplanasinya berdasarkan teoritis yang dianutnya yaitu eksplanasi interpretif. 


\section{Daftar Pustaka}

Barnard, Alan (1998) Encyclopedia of Social and Cult dan ural Anthropology, Routledge, New York.

Bernard, H.Russel (1994) Research Method in Anthropology: Qualitatif and Quantitatif Approaches, Sage Publication, London.

Biezeveld, Renske (2002) Between Individualism and Mutual Help: Social Security and Resource in a Minangkabau Village, Eburon, Delft.

Ellen, R.E, Ethnographic Reaearch: A Guide to General Conduct, Academic Press, London.

Fetterman, David M. (1989) Ethnography Step by Step. Sage, London.

Gay y Blasco, Poloma and Huon Wardle (2007) How To Read Ethnography, Routledge, London.

Geertz, Hildred (1985), Keluarga Jawa, Grafiti Pers, Jakarta

Heider, Karl G. (1997) Seeing Anthropology:Cultural Anthropology Through Film, Allyn and Bacon, Boston.

Katz, Jack (2001)"From how to why. On luminious description and causal inference in ethnography (Part I)," Ethnography 2(4):443-473.

Katz, Jack (2001)"From how to why. On luminious description and causal inference in ethnography (Part II)," Ethnography 3(1):43-90.

Koentjaraningrat (1980) Sejarah Teori Antropologi, UI Press, Jakarta.

Lewis, Oscar (1988), Kisah Lima Keluarga: Telaah-telaah Kasus Orang Meksiko Dalam Kebudayaan Kemiskinan, Yayasan Obor, Jakarta.

Simon, Gregory M. (2007) "Caged in Outside: Identity, Morality, and Self in an Indonesian Islamic Community". Disertasi, Michigan.

Tsing, Anna Lowenhaupt (1998), Di Bawah Bayang-Bayang Ratu Intan, Yayasan Obor Indonesia, Jakarta.

(2005), Friction: An Ethnography of Global Conection, Princeton University Press, Princeton. 